\title{
Scenario of Biomedical Waste Management during COVID-19 Pandemic in Delhi, India
}

\author{
Divyanshu Aneja ${ }^{1}$, Anshul Rana ${ }^{1}$, Anjali Kumari ${ }^{1}$, Anunay A. Gour ${ }^{1}$ \\ Department of Environment Engineering, Delhi Technological University \\ Bawana Road, Delhi, India \\ ${ }^{1}$ 1999divyanshu.aneja@gmail.com \\ ${ }^{1}$ rananshul94@gmail.com \\ ${ }^{1}$ miss.anjali.g@gmail.com \\ ${ }^{1}$ Corresponding author, ${ }^{4}$ anunaygour@dtu.ac.in \\ DOI: $10.51201 / J U S S T / 21 / 05266$ \\ http://doi.org/10.51201/JUSST/21/05266
}

\begin{abstract}
The COVID-19 pandemic has resulted in a significant rise in the production of biomedical waste in India's healthcare waste management system. Authorities in Delhi are finding it increasingly difficult to maintain and treat large volumes of biomedical waste as the volume of biomedical waste continues to rise.In addition to the COVID19-related biomedical waste to segregate and dispose of, a huge strain has been imposed on the health-care management system.This research examines the current state of biomedical waste management in Delhi, India as well as the past and present state of biomedical waste generation in various hospitals of Delhi. In this study, the five private hospitals of Delhi have been taken and the data is taken from their websites respectively. The duration of Waste generation has been taken from the year 2016-2020 for each hospital which has been represented graphically. This paper also covers the quantification of biomedical waste ofDelhi and India from June 2020 to December 2020, highlighting thecomparative analysis of the top 5 States of India producing the largest amount of biomedical waste presented graphically. Apart from that, the study covers the current legal status of biomedical waste management in India (Latest Guidelines and Amendments in BMW Rules, 2016 by Central Pollution Control Board for managing COVID-19 based medical wastes) as well as various advances in treatment technologies for handling large amounts of COVID-19 BMW.The consequences of biomedical waste, which can pose a significant threat to both humans and the environment, have also been addressed. Similarly, various effective measures and latest treatment technologies have been listed in the sense of proper waste management in a holistic manner toward a sustainable future. This research will help officials and other organisations ensure that there is no inefficiency in the system and that all activities are carried out efficiently.
\end{abstract}

Keywords: biomedical waste, management, covid-19, waste characterization, human health waste management

1.0 INTRODUCTION

Biomedical waste is defined as any waste produced during human or animal diagnosis, processes or immunisation or research in laboratories or production of biological testing or in healthcare facilities[1].An increasing amount of hazardous biomedical waste is one of the main consequences of the continuing COVID-19 pandemic in India. The waste generated during a COVID-19 pandemic was estimated at approximately 162 tonnes/day (TPD), the average quantity generated by India in November 2020, according to CPCB survey. In addition to a regular waste quantity, the amount of waste produced during the COVID-19 pandemic is roughly 610 TPD (approx.) per day, on average. From June 2020 until December 2020, India recorded around 32,996.4 tonnes of associated biomedical waste 
COVID-19. From June 2020 to December 2020 Delhi has generated around 2474,323 tonnes of waste, a huge volume of waste over a total of 7 months[2].

Due to the extreme huge quantity of biomedical waste produced by COVID-19 in developing countries like India there is a problem with management and management of biomedical waste because, in accordance with the 2016 Biomedical Waste Management Regulations, it cannot be handled appropriately in large amounts and is another major issue for the environment and human health.Following the implementation of the Indian government, in 2016 the Ministry of the Environment, Forests and Climate Change published Biomedical Waste Management Rules that started to categorise biomedical waste for the purposes of separation in different colour codes and to provide treatment option for each type of waste.Although an amendment in 2018 gets implemented to improve compliance to the BMW Rules, 2016[3]-[4].With the rise in COVID-19 cases in India, the large amount of biomedical waste created by COVID-19 wards and isolation centers has negative consequences for the environment and humansPeople employed in health-care facilities should take precautions and wear protective gear such as boots, aprons, long-sleeved gowns, masks, thick gloves, and goggles or face shields to avoid contamination, according to WHO guidelines.According to a report by WHO, there is no evidence that there is a direct transmission of the COVID-19 virus inside the human body during the handling of health care waste[5].

\subsection{Sources and classification of Biomedical Waste:}

Health centers producing medical wastes are expanding continuously every year in their amount and category. These different categories of waste possess contamination to Human beings and the environment. The waste-producing are of major and minor sources which are stated below: 


MAJOR SOURCES
- Government hospitals
- Private hospitals
- Nursing home
- Apothecaries
- Primary Health Centers
- Medical Colleges
- Research Centers
- Emergency medical services
- Vetenary Institutions
- Animal Research centers
- Blood bank/ Mortuaries
- Necropsy centers
- Biotechnology Centers
- Production Units
- MinOR SOURCES
- Dental Clinics
- Slaughter Houses
- Blood Donation Camps
- Vaccination Centers
- Acupuncture Centers
- Psychiatric centers
- Funeral services
- Disabled Persons Institutions

Figure 1Sources of Biomedical Waste [6]

Table 1 Categories of Biomedical Waste[7]

\begin{tabular}{|c|c|c|c|}
\hline Category & Type of Waste & Treatment and Disposal option & Ref. \\
\hline Category No.1 & Evacuation Waste: organic tissue, organs, body parts, etc. & Incineration/Deep burial & [8] \\
\hline Category No.2 & $\begin{array}{l}\text { Animal Anatomical Waste: Experimental animal carcasses, } \\
\text { animal body parts, animal organs, tissues, animal waste } \\
\text { generated from experimenting or testing in Veterinary } \\
\text { hospitals or slaughterhouses, etc. }\end{array}$ & Incineration/Deep burial & [9] \\
\hline Category No.3 & $\begin{array}{l}\text { Microbiological and Biotechnological waste:Laboratory } \\
\text { culture media and plates, stocks or specimen of } \\
\text { microorganisms, Vaccination wastes, Reagents used in } \\
\text { microbiological laboratories, production of biological, } \\
\text { toxins, dishes, and different devices used in transferring of } \\
\text { cultures, etc. }\end{array}$ & Microwaving/Autoclaving/Incineration & [10] \\
\hline Category No.4 & $\begin{array}{l}\text { Waste Sharps:Wastes such as needles, scalpels, broken } \\
\text { glass, blades, and razors that may cause puncture and cuts } \\
\text { including both used and unused sharps. }\end{array}$ & $\begin{array}{l}\text { Disinfection (Chemical } \\
\text { treatment/Autoclaving/Microwaving) }\end{array}$ & [11] \\
\hline Category No.5 & $\begin{array}{l}\text { Discarded Medicines and Cytotoxic drugs: wastes } \\
\text { comprising discarded medicines, packaging material, } \\
\text { cartons, etc. }\end{array}$ & $\begin{array}{l}\text { Incineration/destruction/disposal of } \\
\text { drugs in landfills }\end{array}$ & [12] \\
\hline Category No.6 & $\begin{array}{l}\text { Soiled wastes:Infectious blood items, body fluids including } \\
\text { dressing, plaster casts, cotton swabs, lined beddings, and } \\
\text { other contaminated blood components, etc. }\end{array}$ & Incineration/Autoclaving/Microclaving & [13] \\
\hline Category No.7 & $\begin{array}{l}\text { Solid Wastes: Wastes produced from disposable items other } \\
\text { than sharps wastes such as tubings, catheters, intravenous } \\
\text { sets, etc. }\end{array}$ & $\begin{array}{l}\text { Disinfection (Chemical } \\
\text { treatment/Autoclaving/Microwaving) }\end{array}$ & [14] \\
\hline Category No.8 & $\begin{array}{l}\text { Liquid wastes:Wastes produced from laboratory and } \\
\text { washing, cleaning, housekeeping, and disinfecting } \\
\text { activities, etc. }\end{array}$ & $\begin{array}{l}\text { Disinfection (Chemical treatment) and } \\
\text { discharging into drains. }\end{array}$ & [15] \\
\hline Category No.9 & $\begin{array}{l}\text { Incineration Ash:Ash releasing from the Incineration } \\
\text { process any biomedical wastes. }\end{array}$ & $\begin{array}{l}\text { Disposal into a secured municipal } \\
\text { landfill }\end{array}$ & {$[16]$} \\
\hline Category No.10 & $\begin{array}{l}\text { Chemical Wastes: Wastes are generated from the production } \\
\text { of biological and used or discarded disinfectants such as } \\
\text { insecticides, pesticides, etc. }\end{array}$ & $\begin{array}{l}\text { Chemical treatment/discharging into } \\
\text { drains for liquids or in a secured } \\
\text { landfill. }\end{array}$ & [17] \\
\hline
\end{tabular}




\subsection{Characterization of Biomedical Waste:}

General waste ranges from $\mathbf{7 5 \%}$ to $\mathbf{9 0 \%}$ which includes health-care waste and These wastes aren't harmful in any way. These wastes originate from the kitchen, administrative, Housekeeping facilities generated at healthcare centers. It also covers packaging waste and waste generated during the upkeep of healthcare facilities. About $\mathbf{1 0 \%}$ $\mathbf{2 5 \%}$ of extravagance is dangerous. These types of wastes may cause a threat to variation of atmosphere and disease. The remaining i.e.,5\% of waste is chemical or radioactive waste which is also hazardous. These are types of waste from sealed sources, like diagnostic tools, that can cause wounds along with destruction of the tissue, which require amputation of the body parts, etc.[18].

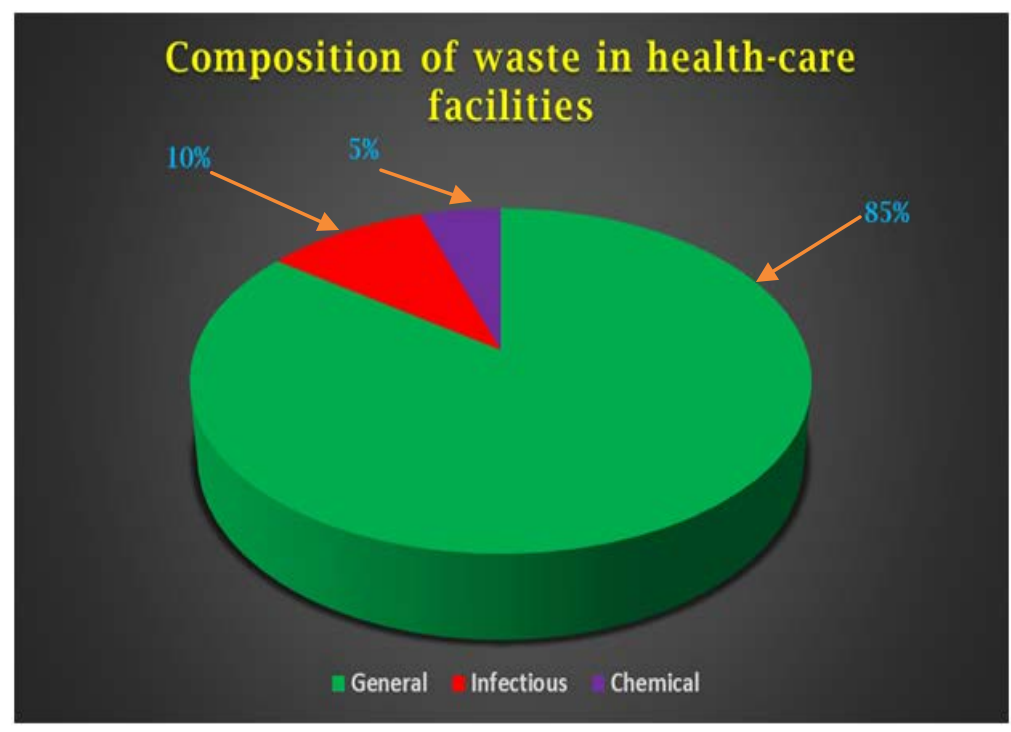

Fig.2: Composition of waste in Health care facilities

\subsection{THE CURRENT LEGAL STATUS OF BIOMEDICAL WASTE MANAGEMENT IN INDIA:}

In the context of the management of biomedical waste created by various sanitary facilities throughout the country, the Government of India issued a regulation in 1998 on biomedical waste management and handler.In the Gazette of India, these rules were published in 1998. These rules for the management of biomedical waste are periodically updated to manage and treat different types of waste generated in hospitals. New Biomedical Waste Management rules in 2016, issued by the Indian government in March 2016, were substituted for the 1998 biomedical Waste Management Regulations. These rules consist of the new definition of biomedical waste, occupier, and operator, and prescribed authority[19].Also, these rules consist of five forms and four schedules which are stated below:

Schedules: Four schedules describe waste categories, label schemes, standards of disposal \& prescribe duties.Schedule-1: It outlines waste types, the appropriate bag or container to use, and disposal choices.Schedule-2: It includes guidelines for incineration, autoclaving of biomedical waste, microwaving/deep burial/chemical disinfection efficacy/dry heat sterilization/liquid waste, and so on.Schedule-3: It provides a catalog of dictate authorities \& corresponding duties.Schedule-4: It includes a list of the biomedical waste container or bag labels as well as a label for transporting biomedical waste bags or containers. 
Forms: It provides Performa of various forms that can be used for filling applications, complaints, and annual reports in BMW rules, 2016. Below given is the purpose of various forms. Form-1: It is for accident reporting.Form2: It is a request for permission or a request for the renewal of power.Form-3: It is for authorization. Form-4: It is the format of an annual report. Form-5: It is an appeal against a decision made by the prescribed power.

The latest amendments were carried out in Feb 2019 \& May 2019 which were known as Biomedical Waste (Management \& Handling) Rules, 2019. The main highlights of the first new Biomedical Waste (Management and Handling) Rules, 2019, published in February 2019, are listed below[20].Every day, all bedded health care units should be maintained and modified, and biomedical waste management must register and view all information on its website in accordance with the biomedical waste generation schedule in terms of category and color-coding. Such health care facilities (with any number of beds) must prepare an annual report and post it on their website within two years of the publication date of the Biomedical Waste Management Rules, 2018. By December 31, 2019, health care facilities with less than ten beds must comply with the production discharge requirement for liquid waste.Key highlights for Biomedical Waste Management rules, 2019 which were done in May 2019[21]thatChlorinated bags should not consist of urine bags, effluent bags, abdominal bags, and chest drainage bags.

\subsection{CPCB Guidelines for managing COVID-19 waste in India:}

СРCB has issued the first three revisions of guidelines for managing COVID-19 waste which was first released on March 2020 and then is subsequently revised and updated on April 2020 \& on June 2020. It published the fourth revision of guidelines for the handling, care, and disposal of waste produced during COVID-19 patient treatment, diagnostics, and quarantine in July 2020. The position of Common Biomedical Waste Treatment Facilities, State Pollution Control Boards, and Urban Local Bodies is also outlined in these recommendations[22].In isolation compartments or quarantine centres, there should be adequate color-coded bins, receptacles, or containers, as well as proper waste segregation in compliance with the Biomedical Waste Management Rules, 2016.Doubled Layer bags should be used to collect or store waste from COVID-19 isolation wards for testing or ensuring zero leakage (or by using two bags). There should be a dedicated or labelled collection bin and a temporary storage area for biomedical waste until it is handed over to Approved Staff at the Common Biomedical Waste Treatment Facility (CBWTF) for prior treatment and immediate disposal.Separate data of waste produced in COVID-19 sick birth or Quarantine Centers should be kept.

COVID-19 waste should be stored in tanks, garbage cans, and grip cars that have been decontaminated with a 1 percent sodium hypochlorite solution regularly (daily).COVID-19 isolation wards and COVID-19 ICU wards to SPCBs and their unique CBWTF found in the area were recorded in the journal. Sanitation personnel committed to biomedical waste collection and transportation to a temporary waste storage area on a daily basis.Common trash which is produced from detachment should be passed over to garbage dump recognized by the city government.Biomedical waste produced in detachments or camps should be segregated and collected in yellow bags allocated for collection by Urban Local Bodies (ULBs).After getting a receipt from CBWTF, COVID-19 waste should be disposed of as soon as possible.The CBWTF then uses any of the licenced methods in accordance with the 
Biomedical Waste Management Rules of 2016. Any of these methods include incineration, plasma pyrolysis, autoclaving or hydroclaving, microwaving, and chemical disinfection.

\subsection{METHODOLOGY}

The methodology in this study is divided into two phases. Initial Phase -during this phase, information was gathered from various journal articles, websites, government websites, and research papers. Various literatures have been studied in order to gain and comprehend knowledge about the history and current state of Biomedical Waste Management.

Final Phase - from August 2016 to July 2020, data on biomedical waste generation were collected from five different hospitals in Delhi. The total amount of biomedical waste generated by each hospital has been calculated in terms of year-on-year generation. Similarly, the quantification of biomedical waste for each colour coding container, namely yellow, red, white, and blue containers, has been calculated by adding the total sum of four types of waste containers from August 2016 to July 2020. The value was calculated in tons per annum (on a monthly average basis x 12 months). Aside from that, a comparative analysis of waste generation in five hospitals is estimated using the study's above data analysis. Furthermore, the COVID-19-related biomedical waste generation data for Delhi and India as a whole from (June 2020 - December 2020). Finally, the top five major Indian states producing a large amount of COVID-19 related Biomedical Waste data are represented and calculated from (June 2020 - December 2020).

\subsection{RESULT AND DISCUSSION}

A CPCB (Central Pollution Control Board) has issued the status of inventory control for BMWM in Delhi, 2019.

Table 2Biomedical waste management scenario in Delhi, India for the year 2019 [23]

\begin{tabular}{ll}
\hline Inventory & Quantity \\
\hline Total no. of Bedded Health Care Facilities (HCFs) & 1225 \\
Total no. of Non-bedded Health Care Facilities (HCFs) & 9052 \\
Total no. Health Care Facilities (HCFs) & 10227 \\
Total no. of Beds & 57653 \\
Total no. of HCFs applied for authorization & 6033 \\
Total no. of HCFs granted authorization & 5444 \\
Total no. of HCFs in operation without & 0 \\
No. of HCFs utilization CBWTFs & 10227 \\
Total Quantity of BMW generated (kg/day) & 28785.15 \\
Total Quantity of BMW Treated and Disposed (kg/day) & 28785.15 \\
No. of HCFs having Captive Treatment Facilities & 1 \\
No of Captive Incinerators Operated by HCF & 1 \\
CBWTFs Operational & 2 \\
BWTFs under Construction & 0 \\
Deep burial installed by HCFs & 0 \\
Deep burial installed by CBWTFs & 0 \\
Total BMW treated by captive treatment facilities (Kg/day) & 302.15 \\
Total BMW treated by CBWTFs (kg/day) & 28483 \\
Total no. of violation by HCFs \& CBWTFs & 3597 \\
Total No. of show cause notices/Directions issued to defaulter HCFs/CBWTFs & 1004 \\
No. of CBWTFs that have installed OCEMS & 2 \\
\hline
\end{tabular}


4.1 Quantum of BMW Generation of various Hospitals in Delhi
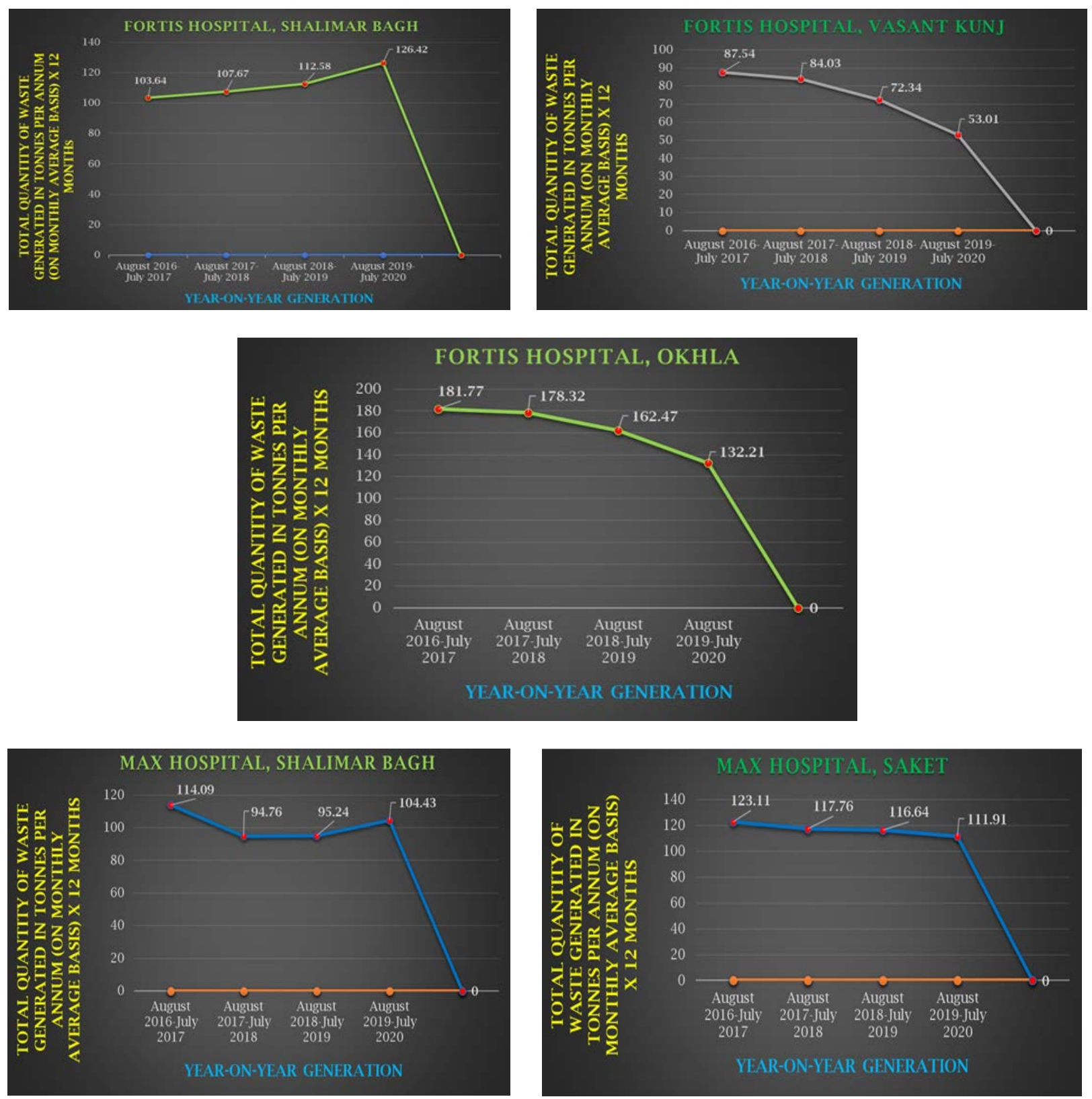

Fig.1: Biomedical Waste Generation at Delhi from August 2016 to July 2020.

Fortis Hospital, Shalimar Bagh - The total amount of biomedical waste generated from August 2016 to July 2017 was 103.64From August 2017 to July 2018, the amount of biomedical waste generated was 107.67. The total amount of biomedical waste generated from August of 2018 to July of 2019 was 112.58. The amount of biomedical waste generated during the year 2019 in the month of August until 2020 in the month of July was 126.42[24].

Fortis Hospital, Vasant Kunj - The amount of biomedical waste generated from August 2016 to July 2017 was 87.54. The total amount of biomedical waste generated from August 2017 to July 2018 was 84.03. The total amount of biomedical waste generated from August 2018 to July 2019 was 72.34. The amount of biomedical waste generated during the year 2019 in the month of August until 2020 in the month of July was 53.01[25]. 
Fortis Hospital, Okhla - The amount of biomedical waste generated from August 2016 to July 2017 was 181.77.The amount of biomedical waste generated from August 2017 to July 2018 was 178.32. The amount of biomedical waste generated from August 2018 to July 2019 was 162.47. The amount of biomedical waste generated during the year 2019 in the month of August until 2020 in the month of July was 132.21[26].

Max Hospital, Shalimar Bagh - The amount of biomedical waste generated from August 2016 to July 2017 was 114.09. The amount of biomedical waste generated during the year 2017 in the month of August to the month of July in 2018 was 94.76. The total amount of biomedical waste generated from August of 2018 to July of 2019 was 95.24. From August 2019 to July 2020, the amount of biomedical waste generated was 104.43[27].

Max Hospital, Saket -The amount of biomedical waste generated from August 2016 to July 2017 was 123.11. From August 2017 to July 2018, the amount of biomedical waste generated was 117.76. The amount of biomedical waste generated in the year 2018 in the month of August until 2019 in the month of July was 116.64. The amount of biomedical waste generated from August 2019 to July 2020 was 111.91[28].
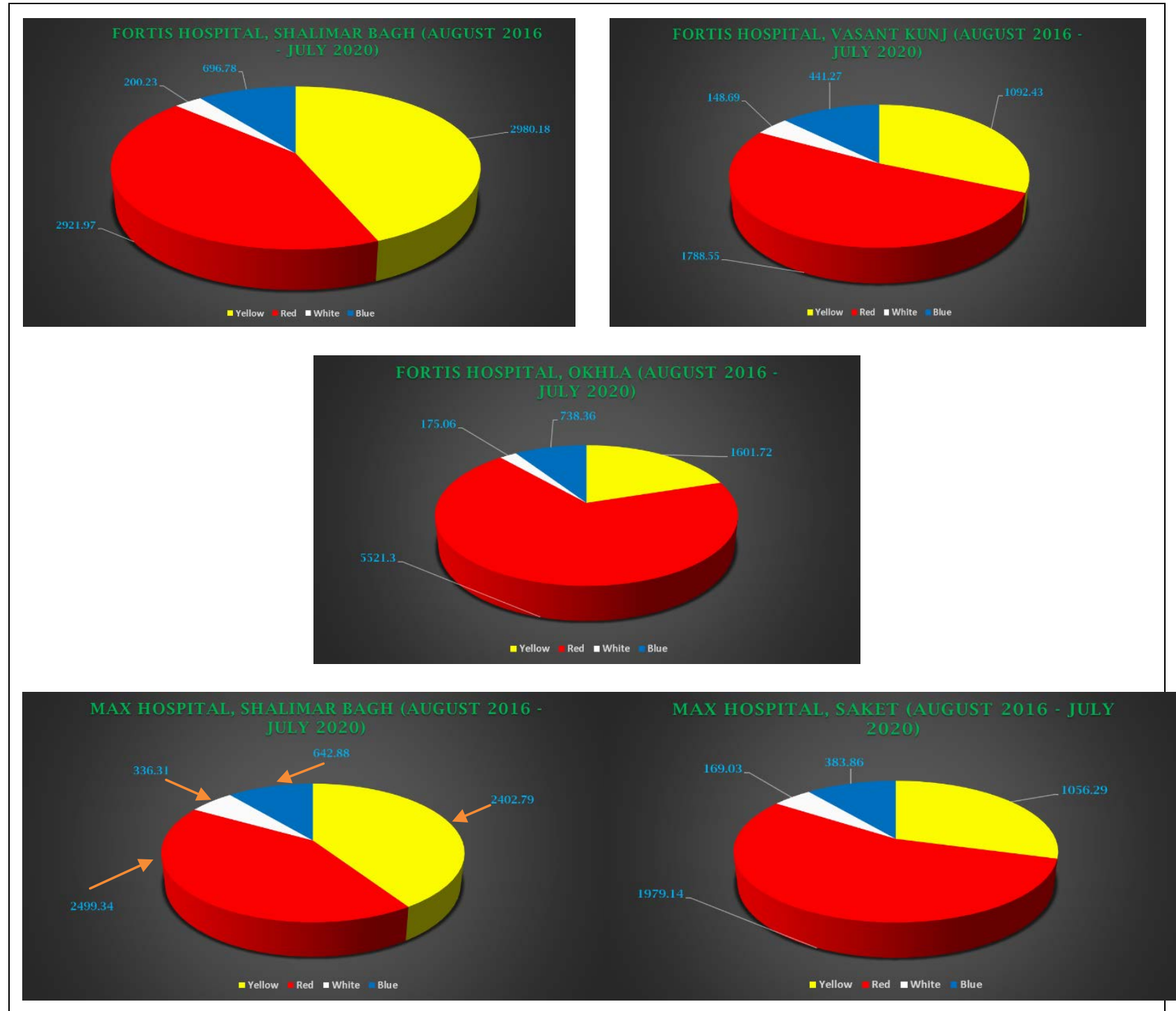

Fig.2: Category-wise biomedical waste generation at various hospitals in Delhi from August 2016 to July 2020. 
Fortis Hospital, Shalimar Bagh:In the yellow category, the actual number of biomedical wastes produced from August 2016 to July 2020 was 2980.18. The total number of biomedical wastes produced in the category of red from August 2016 to July 2020 was 2921.97. Overall biomedical waste produced in the white category between August 2016 and July 2020was 200.23. The overall sum of biomedical waste produced in the blue category from August 2016 to July 2020 was $696.78[24]$.

Fortis Hospital, Vasant Kunj - The total amount of biomedical waste generated in the yellow category from August 2016 to July 2020 was 1092.43 . The actual amount of biomedical waste produced in the red category from August 2016 to July 2020 was 1788.55 . The total amount of biomedical waste generated in the white category between August 2016 and July 2020 was 148.69. The overall sum of biomedical waste produced in the blue category between August 2016 and July 2020 was 441.27[25].

Fortis Hospital, Okhla - In the yellow category, the actual amount of biomedical waste producedfrom August 2016 to July 2020 was 1601.72. The overall sum of biomedical waste produced in the red category from August 2016 to July 2020 was 5521.3. Between August 2016 and July 2020, the total number of biomedical wastes produced in the white category was 175.06. From August 2016 to July 2020, the overall sum of biomedical waste produced in the blue category was $738.36[26]$.

Max Hospital, Shalimar Bagh - The overall sum of biomedical waste produced in the yellow category from August 2016 to July 2020 was 2402.79. From August 2016 to July 2020, the overall sum of biomedical waste created in the red category was 2499.34. Between August 2016 and July 2020, the total number of biomedical wastes produced in the white category was 336.31. From August 2016 to July 2020, the actual amount of biomedical waste produced in the blue category was 642.88[27].

Max Hospital, Saket - From August 2016 to July 2020, the amount of biomedical waste generated in the yellow category was 1056.29. In the red category, the actual amount of biomedical waste producedfrom August 2016 to July 2020 was 1979.14. In the case of the white category, the amount of biomedical waste generated from August 2016 to July 2020 was 169.03. Between August 2016 and July 2020, the actual amount of biomedical waste produced in the blue category was 383.86[28].

4.2 Quantity of Waste of the 5 hospitals (August 2016 - July 2020):

The quantity of biomedical waste produced by Fortis Hospital, Shalimar Bagh during the year 2016 in the month of August until 2020 in the month of July was 450.33. The total amount of biomedical waste generated by Fortis Hospital, Vasant Kunj from August 2016 to July 2020 was 296.93. The amount of biomedical waste generated at Fortis Hospital, Okhla from August 2016 to July 2020 was 654.78. Max Hospital, Shalimar Bagh generated 408.54 of biomedical waste from August 2016 to July 2020. Between August 2016 and July 2020, the overall sum of biomedical waste produced in the Max Hospital, Saket was 469.44[24],[25],[26], [27],[28]. 
5.0 COVID-19 RELATED BIO-MEDICAL WASTE GENERATION IN DELHI, INDIA IN 2020:

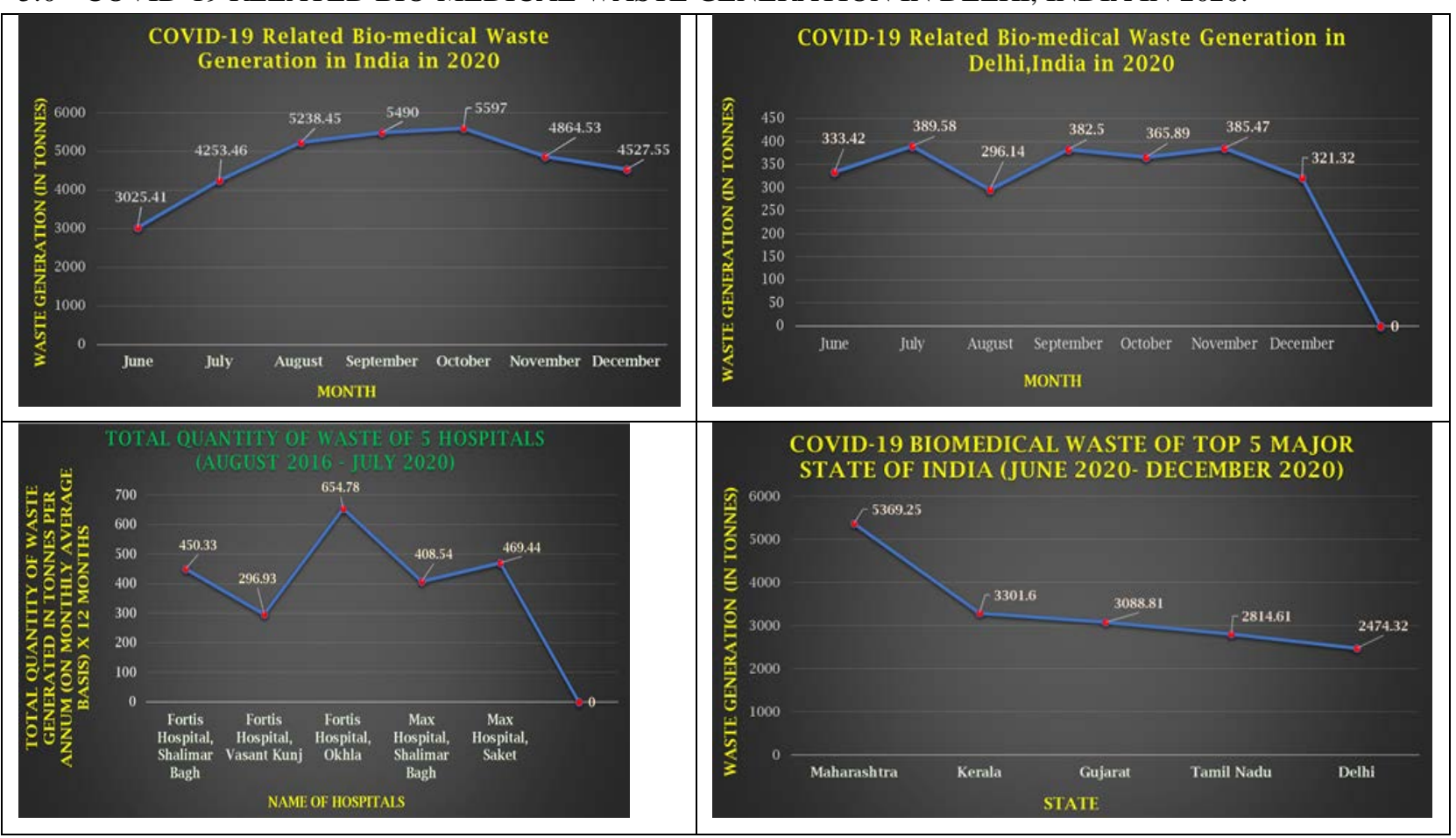

Fig.16: COVID-19 related BMW scenario (June 2020- December 2020)

In the month of June 2020, the amount of COVID-19-related biomedical waste generated in Delhi, India was 333.42. Likewise, the amount of COVID-19 biomedical waste generated in Delhi, India in July 2020 was 389.58. Similarly, in August 2020, the amount of COVID-19 biomedical waste generated in Delhi, India was 296.14. Moving on, the quantity of COVID-19 biomedical waste generated in Delhi, India in September 2020 was 382.5. The amount of COVID-19 biomedical waste generated in Delhi; India in October 2020 was 365.89. As months went on, the amount of COVID-19 biomedical waste generated in Delhi, India in November 2020 was 385.47. With the passage of time, the quantity of COVID-19 biomedical waste generated in Delhi, India in December 2020 reached 321.32[29].

5.1 COVID-19 Related Bio-medical Waste Generation in India in 2020:

The quantity of biomedical waste produced in Delhi, India, as a result of COVID-19in June 2020 was 3025.41. Similarly, the sum of COVID-19 biomedical waste produced in Delhi, India in July 2020was 4253.46. Correspondingly, the amount of COVID-19 biomedical waste generated in Delhi, India in August 2020 was 5238.45. Heading on, in September 2020, the amount of COVID-19 biomedical waste generated in Delhi, India was 5490. In October2020, the amount of COVID-19 biomedical waste generated in Delhi, India was 5597. With the passage of time, the amount of COVID-19 biomedical waste generated in Delhi, India in November 2020 reached 4864.53. And then, in December 2020, the amount of COVID-19 biomedical waste generated in Delhi, India reached 4527.55[29]. 
5.2 Covid-19 Biomedical Waste of Top 5 Major States (June 2020- December 2020:

Maharashtra is one of India's leading producers of biomedical waste; the quantity of biomedical waste generated by COVID-19 from June 2020 to December 2020 was 5369.25. Moving on, Kerala ranks second with a total of 3301.6 of COVID-19-related biomedical waste generated from June 2020 to December 2020. Gujarat is placed third, with 3088.81 tonnes of COVID-19-related biomedical waste generated between June 2020 and December 2020. Similarly, Tamil Nadu takes fourth spot with a total of 2814.61 of COVID-19-related biomedical waste generated between June 2020 and December 2020. Finally, with a total of 2474.32 of COVID-19-related biomedical waste generated between June 2020 and December 2020, Delhi moves up to fifth place[29].

\subsection{IMPACT OF BIOMEDICAL WASTE ON ENVIRONMENT AND HUMAN HEALTH}

6.1 Impact of Biomedical Waste on Water Quality:

The inappropriate disposal of biomedical waste is having a negative impact on the quality of water, as various contaminants are released into the groundwater from dumping areas.Al Raisi[30]assessed and monitored heavy metals in the leachate that exceeded standards for drinking water. $\mathrm{Al}, \mathrm{V}, \mathrm{Cr}, \mathrm{Mn}, \mathrm{Co}, \mathrm{Ni}, \mathrm{Ba}, \mathrm{Pb}$ and $\mathrm{Fe}$ values2.050,0.9775,2.800,0.503,0.128,0.8575,0.130, and $39.25 \mathrm{mg} / \mathrm{L}$.Surface and groundwater contamination were considered the effect of these pollutants.The effect of a practical and unwanted waste dump on the nature of adjoining groundwater in Lagos Nigeria was similarly evaluated by Oluseyi[31].In wells near the useful waste disposal site of Olusosun, it was found that the mean concentration of the physicosynthetic limits was higher.The limits of different metals for wells in the vicinity of the Oke-Afa dumpsite and for wells in the area near the Olusosun dumpsit were admissible to both the WHO and the NSDWQ at both dumps locations, which had the mean $0.069 \pm 0.075 \mathrm{mg} / \mathrm{L}$.Kanmani[32]investigated the substantial contamination of metals by municipal solid waste (MSW) and open dumps to include the transfer of leachates from an open site to groundwater.The examination was completed at waste dumps that are approximately 400-700 tonnes. The presence of $\mathrm{Mn}, \mathrm{Pb}, \mathrm{Cu}$, and $\mathrm{Cd}$ was high in metals and the probability of movement from the open discharge site was high.Heera[33]shows the high level of heavy-metals and polycyclic aromatic hydrocarbons (PAHs) in biomedical waste consumption, leading to negative measurements of hazardous materials and contamination of surface and groundwater.It is therefore essential to remove toxic waste in waste or reuse before removal.The study showed an increase in the hardness $(1320 \mathrm{mg} / \mathrm{L})$ and chloride content (8500 mg/L) of BMW ash in leachate, as far as possible defined in the World Health Organisation's and the EPA rules.The Sewapura MSW dumping site near Jaipur was evaluated by Gautam[34].In examined tests with greater scope of satisfactory cutoff points, high levels of fluoride (2.4-3.2 mg/L), chlorides (288.4-1038.2 $\mathrm{mg} / \mathrm{L}$ ) and TDS (610.4-1828.4 $\mathrm{mg} / \mathrm{L}$ ) were found.The soil is contaminated by toxic substances being burned by MSW and should subsequently be limited by the specialists concerned. Al Raisi[30]researched that there is a danger in the climate, particularly in unlinear landfills, where the dispersal of leachate into groundwater can occur, from heavy metals in waste sludge from biomedical waste.Tests on leachate from Oman's leachate pools located behind the site were collected.The results revealed that certain substantial metals found in leachate exceeded the standards of drinking water and waste water reuse and sultanate release rules for a total of 2,050,0.9775, 2800,0.503,0.128,0.773,0.8575, 0.130 and 39,25 mg/L of Al, V, Cr, Mn, Co, Ni, Ba, Pb and Fe. In all, sultanate release standards were found. 
6.2 Impact of Biomedical Waste on Air Quality:

Incorrect disposal and burning of biomedical waste damages the environment and includes the combination of various pollutants at a risk to human health and the environment. Karthikeyan[35] claimed to be considered a difficult issue from municipal solid waste dumping destinations as ozone depleting substances and particulate emanations. Medical waste consumption in these locations is a real danger to the environment and humans. It releases toxins that cause the occupant to suffer from various kinds of respiratory problems. Their investigation showed the significant types of PM10 and PM2.5 in dust, black carbon, alkalis, sulphates and nitrate. During the late spring the particles were detected as high as the rainstorm. The critical variation was noted between the examples and ranged between 211 and $900 \mu \mathrm{g} / \mathrm{m} 3$ and went beyond the recommended Central Pollution Control Board's maximal reach of $150 \mu \mathrm{g} / \mathrm{m} 3$ (CPCB). Additional perilous mixtures such as dioxide, decane, dodecane, octane, nonane, methenamine, cyclobutane, carbon disulfide, and CH3)2CO peroxide have polluted the ambient air samples. Javied[36] has examined the huge amount of waste that is supervised by combustion plants produced by hospitals. The consumption of clinical waste nonetheless contaminates the climate by burned waste fly debris and toxic metals. The irresistible waste age of hospitals is determined by incinerators consumed in different medical clinics in Pakistan. The $\mathrm{Cd}, \mathrm{Cr}, \mathrm{Cu}, \mathrm{Pb}$, and $\mathrm{Zn}$ measurements have shifted from one day to the next, from hospitals to hospitals and a clinical waste-connected incinerator to a hospital-based waste. $\mathrm{Pb}$ and $\mathrm{Zn}$ abundance in clinical waste has been found to be moderately higher than that of various components. The usual grouping of $\mathrm{Pb}$ for medical residues was 3.9, 3.2, and $4.6 \mu \mathrm{g} / \mathrm{g}$, although $\mathrm{Zn}$ was separately $6.6,5.3$ and $6.7 \mu \mathrm{g} / \mathrm{g}$. The origin of the burned ash was the presence in the waste of polyvinyl chloride. Zhao[37] has taken $22 \mathrm{HW}$ debris tests, including 14 base ash and 8 fly ash samples from four normal HW combustion plants in China. The results showed that the HW cinders contains many metal salts of 1,8-315 g kg-1 from $\mathrm{Al}, \mathrm{Ca}, \mathrm{Fe}, \mathrm{K}, \mathrm{Mg}$ and $\mathrm{Na}$. In addition, the cinders are immersed in the immensely large cylinders of 1.1-121,411 Mg kg-1, with substantial metals as $\mathrm{Ag}, \mathrm{As}, \mathrm{Ba}, \mathrm{Bi}, \mathrm{Cd}, \mathrm{Cr}, \mathrm{Cu}$, $\mathrm{Mn}, \mathrm{Ni}, \mathrm{Pb}, \mathrm{Ti}, \mathrm{Sb}, \mathrm{Sr}, \mathrm{Sr}$ and $\mathrm{Zn}$.Cd was also found in the interchangeable portions and carbonates, and As, Mn, Zn was found in the $\mathrm{Fe}-\mathrm{Mn}$ division of oxides. The results of the TCLP showed that the drained $\mathrm{Cd}, \mathrm{Cu}$, and $\mathrm{Pb}$ measures were exceeding USEPA levels from virtually all of the fly ash tests. The study between HW cinders and MSW ash has shown the substantial grades of $\mathrm{Cr}, \mathrm{Cu}, \mathrm{Pb}, \mathrm{Ti}, \mathrm{Ag}, \mathrm{As}, \mathrm{Bi}, \mathrm{Cd}$ and $\mathrm{Zn}$ of the $\mathrm{HB}$ base and flue ashing.The dispensing of risky irresistible waste in sites without the rules of the Illinois Pollution Control Board in Illinois City was limited by the hospitals. Dangerous combustion of plastic-rich waste is not as expected.The hydrochloric corrosive, carbon monoxide, ethane, ethylene, propane, and propylene outflows from incinerators were estimated to be 3.3-5.3, 1.4-1.8, 0.002, 0.010, 0.012, and $0.011 \mathrm{~g} / \mathrm{kg}$, respectively Allen[38].Giusti[39] examined the options available to the European Union (EU), the Organization for Economic Cooperation and Development (OECD), and a few developing countries. Furthermore, he investigated the potential immediate and backhanded effects of waste administration exercises on humans, with special emphasis on bio-pressurized canned goods and microorganisms. Hundreds of epidemiological studies revealed the prevalence of a wide range of potential illnesses among waste facility workers and the general population.The study concluded that evidence of adverse health outcomes for people living near landfills, incinerators, composting facilities, and atomic establishments is generally insufficient and uncertain. The majority of the studies took into account the high risk of gastrointestinal issues caused by microbes that begin in sewage treatment plants.Coutinho[40] proposed that an enormous data set of 
dioxin and furan abundance on the climate of the Porto metropolitan territory is due to two clinical waste incinerators operating in downtown Porto. The dioxin concentration was estimated to be 100-1000 times higher than the new European Union order limits. The completion of these units had an impact on the improvement of air quality in the area.According to Ephraim[41], improper biomedical waste management leads to serious outbreaks such as SARS. Hospital waste is frequently not properly disposed of; additionally, the impact of this waste on the soil near medical clinics discovered $\mathrm{Si}, \mathrm{Cl}, \mathrm{K}, \mathrm{Ca}, \mathrm{Ti}, \mathrm{V}, \mathrm{Cr}, \mathrm{Mn}, \mathrm{Fe}, \mathrm{Zr}$, and $\mathrm{Pb}$. The presence of $\mathrm{Pb}$ and $\mathrm{Cl}$ is found in abundances ranging from 77.8 3.5-279.6 97.6 and 102.2 37.4-167.2 17.43 ppm, respectively. Because of the rural practises in the area, this is regarded as a genuine health concernLegitimate treatment of medical waste and other hazardous waste is critical because it can cause serious problems for humans and the environment. Sharma[42]claimed that 10-25 percent of the total waste generated by HCF is biomedical waste, which is harmful to humans and the environment. It necessitates explicit treatment. The traditional method for dealing with toxic waste is incineration. Furthermore, incinerators emit a wide range of toxic pollutants during waste disposal, posing a risk to both humans and the environment.Particulate matter, metals, corrosive gases, nitrogen and sulphur oxides, and xenobiotic substances emitted by waste combustion Other issues associated with consuming biomedical waste include global temperature change, fermentation, photochemical ozone or exhaust cloud formation, and eutrophication. Modern advancements in medical waste incineration, for example, hydroclaving and plasma pyrolysis, result in less environmental devastation, immaterial wellbeing impacts, safe treatment of treated wastes, lower operating and support costs, a more powerful reduction of microorganisms, and more secure removal.According to Halder[43], there is a low level of awareness about mercury's toxicity among hospital examinations. A questionnaire survey of doctors/specialists, medical attendants, and experts in various hospitals in Delhi, Uttar Pradesh, and Haryana was used to assess awareness. Respondents' knowledge level, regardless of medical services area, was uniquely between $20 \%$ and $40 \%$.Subrammani[44] revealed that medical waste is a major issue in India, which is the world's second most densely populated country. It has been estimated that there are approximately 6 lakh medical clinic beds available in India. There are also nearly 23,000 primary medical care units and 15,000 small centres and private clinics.Every day, approximately 420,461 kg of biomedical waste is generated in India, with only $240,682 \mathrm{~kg}$ of waste being dealt with.

6.3 Impact of Biomedical Waste on Soil Quality:

Inadequate and absurd biomedical waste disposal may change the quality of the soil at waste dumping sites. Various contaminants mix with the soil and lead to the process of changing the chemical and biological soil ecosystem.Abidemi[45]investigated the levels of five heavy metals in soil (chromium, nickel, zinc, lead, and copper). Zinc (1133 $\pm 897 \mathrm{mg} / \mathrm{kg}$ ), nickel (26.3 $\pm 51.1 \mathrm{mg} / \mathrm{kg})$, copper (110 $\pm 90 \mathrm{mg} / \mathrm{kg})$, lead(137 $\pm 64 \mathrm{mg} / \mathrm{kg})$ and chromium (3.63 $\pm 2.46 \mathrm{mg} / \mathrm{kg}$ ) were concentration of substantial metal in soil. In several inspection areas, the degree of these metals has been greater than background soils with 67(zinc), 18(copper) and 20 components (lead).Auta[46] computed the concentration of thrash metals in soil tests and base debris from an Ibadan hospital incinerator and a civil dumpsite. $\mathrm{Pb}, \mathrm{Fe}, \mathrm{Cu}, \mathrm{Zn}, \mathrm{Cr}$, and $\mathrm{Ni}$ were also tested using atomic nuclear retention spectrophotometry.The heavy metals in the examined soils near the incinerator had mean values of 185.22 72.88, 16.22 13.13, 69.11 54.26, 2.33 2.53, 22.48 21.00, and 0.58 0.30 for Fe, $\mathrm{Cu}, \mathrm{Zn}, \mathrm{Cr}, \mathrm{Pb}$, and $\mathrm{Ni}$, respectively, and the 
mean abundance in the incinerator base ash was 5357.52 4671.89, 938.2 428.42, 106703852.44 , Furthermore, the mean concentrations of soiled samples near municipal dumpsites were 290.67 78.66, 7.86 1.68, 132.87 39.40, 2.58 1.48, 14.52 6.76, and $0.790 .26 \mathrm{mg} / \mathrm{kg}$ for $\mathrm{Fe}, \mathrm{Cu}, \mathrm{Zn}, \mathrm{Cr}, \mathrm{Pb}$, and $\mathrm{Ni}$, respectively. Adama[47] investigated the presence of heavy metals ( $\mathrm{Hg}, \mathrm{Pb}, \mathrm{Cd}, \mathrm{Cr}$, and $\mathrm{Ag})$ in incinerator bottom ash and soils. The analysis discovered a high abundance in $\mathrm{mg} / \mathrm{kg}$ for $\mathrm{Zn}$ (16417.69), $\mathrm{Pb}$ (143.80), $\mathrm{Cr}$ (99.30), and $\mathrm{Cd}$ (7.54) in base debris, but it was within the limits for removal in landfilling areas. This clearly demonstrates that heavy metals pollute soil samples from incinerators and municipal dumping waste.In the landfill climate, Agamuthu[48] identified soil tests from various locations as two waste disposal grounds for thrash metal contamination.Findings demonstrate that all metals were below the Netherlands Soil Remediation Intervention Standards. The concentration of $\mathrm{Pb}$ in the upper layers was higher than in the lower layers. Aside from that, Fe and Zn show a growing pattern of high abundance deep in the soil. The defilement level of these metals was found to be below the level that posed a genuine risk of human exposure during the current investigation. Preparatory measures should be carried out because a higher volume of waste removal will change the force of these metals in the landfill soil in the future.The outcomes were derived from soil samples collected at the Kelana Jaya waste disposal site, which had been heavily polluted by heavy metals exceeding Dutch Intervention levels. Ali[49] evaluated the quality of soil degeneration and vegetation abundance caused by biomedical waste dumping. The physical and synthetic properties of the soil have been significantly affected when compared to control waste disposal destinations. In comparison to the control sites, the soils at these sites had high $\mathrm{pH}$, TDS, and EC systems.In addition to the cadmium which had a high control value with a comparative plant diversity, the concentration of the lead $(\mathrm{Pb})$, copper $(\mathrm{Cu})$, nickel $(\mathrm{Ni})$, chromium $(\mathrm{Cr})$ and zinc was found to be higher in these locations. Amfo-Out [50] tracked normal metal levels in medical waste residues. Incinerated base debris had a mean $\mathrm{Pb}$ concentration of $147.5 \mathrm{mg} / \mathrm{kg}$ and a Cd level of $2.5 \mathrm{mg} / \mathrm{kg}$, whereas the open pit was also $69.67,1.34 \mathrm{mg} / \mathrm{kg}$. All of the metals analysed were classified as destructive and hazardous to humans for Dutch and Danish cutoff values for most extremely low levels of heavy metals, of good soil content. Adegoke[51] used waste disposal of a lead battery to determine soil contamination by substantial metals, and the results showed that lead content outstripped most permissible limits.In inspection destinations the copper level exceeded the maximum permissible groupings of $50 \mathrm{ppm}$. Demie[52]set the concentration and potential effects on the climate and the neighbouring society of heavy metal pollution of soil around open sands. The results showed that there were 0.88, 0.08, 0.06, 0.29, 0.08 and 0.08, individual, in the investigational area, for various heavy metals such as Mn (Mn), Cadmium (Compact Disk), Cobalt(Co), Chromium (Cr), Nickel (Ni).As a result, open landfill sites should be closed in order to lessen future pollution problems. Nazir[53]ascertained the concentrations of heavy metals such as cadmium, zinc, iron, copper, nickel, chromium, and lead in plants, water, and soil. Ukpebor[54] determined the concentrations of various heavy metals in topsoil samples collected from three reject dump locations using nuclear retention spectrophotometry.

6.4 Impact of Biomedical Waste on Human Health:

A great part of the general waste and a very small portion of infectious or dangerous wastes is included in health care waste.Exposure to health care waste may cause serious illness or injury. The nature of health care waste is hazardous is due to presence of infectious agents, its genotoxic nature, presence of toxic or hazardous chemicals, 
Presence of sharps, radioactive nature. Hazards from sharps \& infectious wastes: Infectious waste comprises different varieties of pathogens. These pathogens enter the body throughbreathing, assimilation, mucosa, wound/cut, abrasion in the skin.Given below in Table-III are some examples of different types of infections that are caused by exposure to health care wastes on human beings.

Table 3Types of infections caused by biomedical waste [55]

\begin{tabular}{|c|c|c|c|}
\hline Category of Infection & Infectious Agents & Transmission Route & Ref. \\
\hline $\begin{array}{l}\text { Gastroenteric } \\
\text { Infections }\end{array}$ & $\begin{array}{l}\text { Enterobacteriaceae: Salmonella, Shigellaspp; vibrio } \\
\text { cholera, etc. }\end{array}$ & Feces or vomit liquid & {$[56]$} \\
\hline $\begin{array}{l}\text { Respiratory tract } \\
\text { Infections }\end{array}$ & $\begin{array}{l}\text { Mycobacteria TB, Morbillivirus, Streptococcus } \\
\text { pneumonia, etc }\end{array}$ & Inhaled secretions/ saliva & {$[57]$} \\
\hline Skin Infections & Staphylococcus and Streptococcus & Purulence secretions & {$[58]$} \\
\hline Anthrax & Bacilli Anthraces & Skin oozing & [59] \\
\hline Viral Hepatitis A & Hepatitis A virus & Excrement & {$[60]$} \\
\hline Viral Hepatitis B or C & Hepatitis B or C virus & Blood/ Body fluids & [60] \\
\hline Genital Infections & $\begin{array}{l}\text { Treponema pallidum, Neisseria gonorrhoeae, herpes, } \\
\text { etc }\end{array}$ & Genital secretions & [61] \\
\hline Ophthalmic infection & Herpesviridae & Eyes Secretions & [62] \\
\hline Viral meningitis & Meningococcus & Cerebrospinal fluid (CSF) & [63] \\
\hline AIDS & Human immunodeficiency virus (HIV) & Infected blood, sexual secretions & [64] \\
\hline Hemorrhage fever & Ebola and Marburg, Lassa viruses & $\begin{array}{l}\text { Urine, fecal matter, saliva, or other } \\
\text { body excretions from infected rodents }\end{array}$ & [65] \\
\hline Septicemia & Aureus, Streptococcus species, Enterococcus species & Ingestion or Inhalation & [66] \\
\hline Candida & Candida albicans & Blood & [67] \\
\hline
\end{tabular}

\subsection{MANAGEMENT OF BIOMEDICAL WASTE:}

The management of biomedical waste plays an essential role in our lives because it can have negative impacts on human health and the environment when it is not managed properly. The harmful pollutants releasing from BMW cause severe outbreaks such as respiratory syndrome diseases to human beings and also leads to environmental degradation[68],[69]. There are different medical institutions in India and the management of a substantial quantity of biomedical waste in different healthcare institutions is very difficult.To prevent healthcare-associated contaminations, biomedical waste such as an appendage, limb, structures, blood, and body fluid, as well as soiled linen, bluster, and braces from defile areas, must be properly gathered, segregated, processed, transported, handled, and disposed of[7].The bio-medical waste operations build on the conception of 3Rs that is reducing, recycle, and reuse. Instead of disposing of, the BMW management system focuses to keep away the creation of the waste or recuperation as much as waste as feasible. As a result, there are numerous methods of BMW disposal based on their eligibility, which include prohibit, reduce, recycle, recover, tend, and finally dispose of.Consequently, the waste should be implemented at the origin instead of the "discharge point"[70]. 


\subsection{Various steps for Effective BMWM}

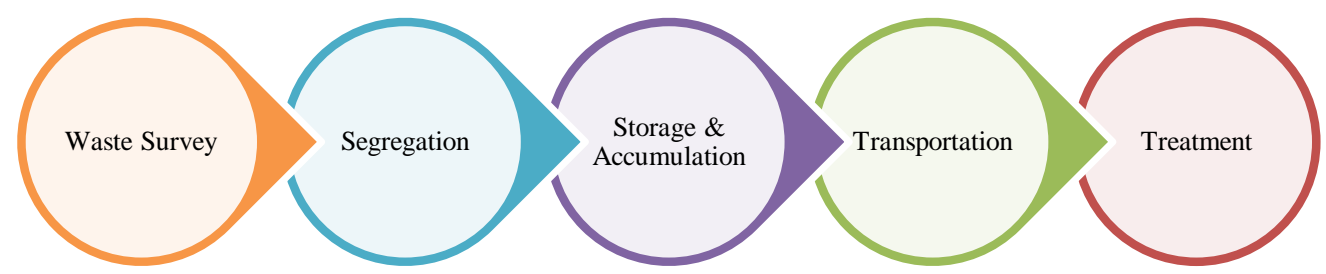

Fig.17: Effective steps for BMWM

\section{a. $\quad$ Waste Survey:}

It is a crucial part of the waste treatment process. A survey aims in deciding the category and quantity of waste generated.A waste survey is essential as it make a distinction between different kinds of waste, identify a number of the waste generated, outline the sources of waste generation and the types of waste generated at each site, assess the hospital's generation and disinfection altitudes, to determine the method of disposal used[71].

\section{b. Segregation:}

Segregation is the primary division of the different forms of waste produced on a daily basis, reducing the risks and costs of handling and disposal.Segregation is the most essential aspect in the management of biomedical waste.Only effective segregation will ensure that biomedical waste is properly managed.The BMWs must be distinguished according to the requirements outlined in Schedule 1 of the BMW Rules, 1998.Different kinds of waste, which lead to reduced costs of infectious waste and disposal, are put into various containers or coded sacks on production stage.Segregation often helps to prevent any transmission of infections and reduces the risk of infecting other healthcare workers. The various color coding is outlined in Fig.18[1].

\section{c. $\quad$ Storage \& Accumulation of Biomedical Waste:}

Waste accumulates and is deposited in the areas and steps between the point of waste generation and the site of waste management and recycling. While waste accumulation refers to the temporary storage of small quantities of waste close to the point of generation, waste storage is defined by longer storage periods and large waste volumes. In most cases, storage facilities are close to where the waste is stored. Any offsite waste storage is often referred to as storage.Various forms of bins are used for waste management.The barrels or bins should be placed in such a manner that they collect $100 \%$ of the debris.Sharps should be kept in puncture-proof bins to prevent contamination and infection of staff who handle them.Biomedical waste is deposited in the appropriate place after storage, and isolated wastes of various forms must be placed in separate containers or bins.In major hospitals, the duration does not exceed 8-10 hours, and in nursing homes, it should not extend to 24 hours.Each bin or container should be named with the ward or room it is stored in. This labeling is essential in case the waste has to be traced back to its source.Furthermore, a cautionary sign should be shown for the storage site. 


\section{d. $\quad$ Transportation of waste:}

Carts and bins that are not used for any other use may be used for the transport of bio-medical wastes. Each day, the trolleys must be washed. The name and address of the transport agent should be shown on the offsite carrier truck. Dyed should be the Biohazard Warning. The appropriate weight-security device should be guaranteed during transportation. A mode of transportation with rounded corners should be conveniently cleanable. Before disposing of the supplier, all disposable plastics should be shredded. Not longer than 48 hours of unprocessed bio-medical waste[72],[73].

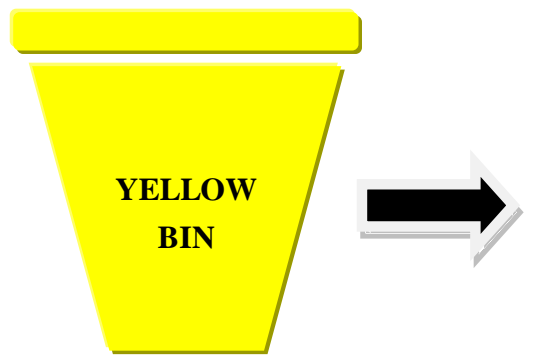

Human/Anatomical Waste Soiled Waste, Expired Medicine Chemical waste, Body Fluids, Clinical Waste
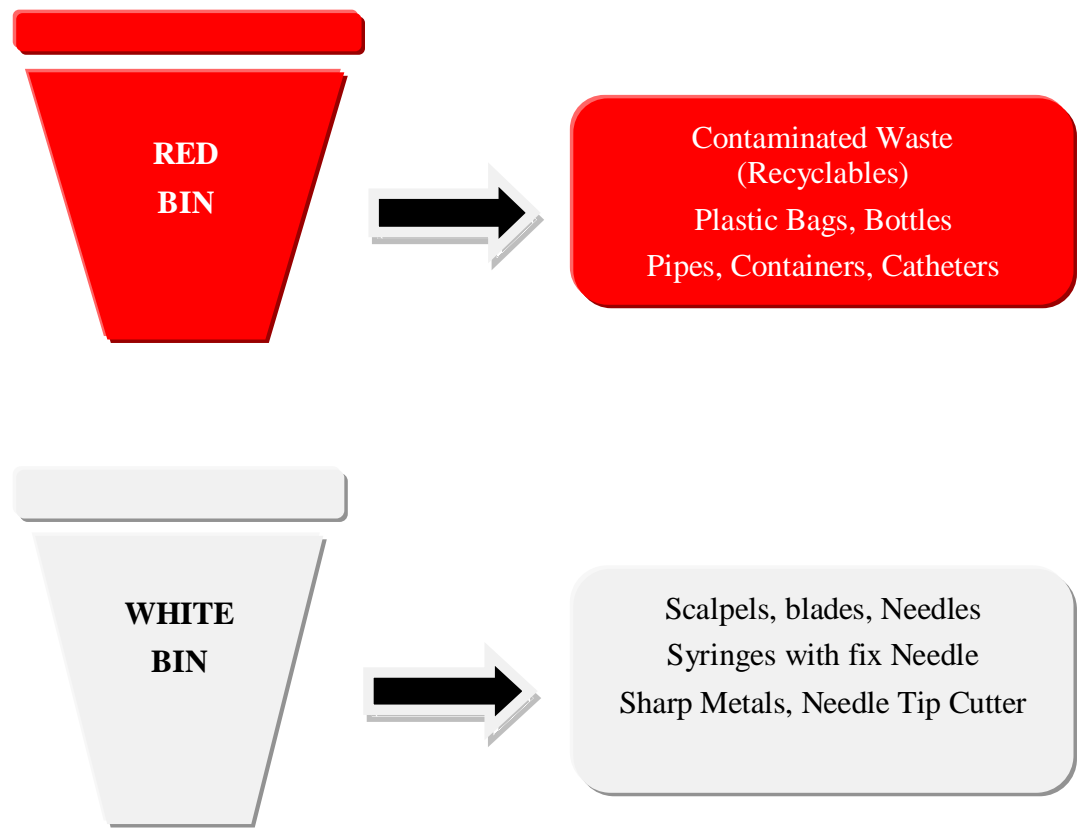

Scalpels, blades, Needles

Syringes with fix Needle Sharp Metals, Needle Tip Cutter
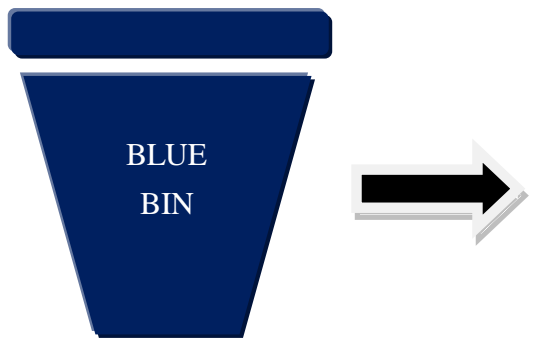

Broken Glassware, Cytotoxic Waste

Metallic Body Implant

Contaminated Glasses including medicine vials

Fig-18: Various color coding for Managing Biomedical Waste 
e. $\quad$ Treatment of waste:

Treatment is the method of changing the waste in some way until it reaches its final resting place.The key prerequisite is that the waste is disinfected or separated from the source to no longer be a source of disease. The residues can be safely extracted, shipped, and preserved after such care.In syringe cutters and needle destroyers, syringe nozzles and needles should be shredded.Broken / Scalpel blades/ Lancet can be stored in separately bleached contains moved to plastic/cardboards; closed and shipped to incubators for spillage prevention.Cleaning, sterilization, and disinfection of glassware should be done.Culture plates must be autoclaved if possible, and media should be placed in suitable bags before being discarded. The plates can be used again after sterilisation. Gloves should be torn or mutilated before disposal. Swabs must be chemically sterilised and then incinerated. If they have a small amount of blood on them that hasn't dried up, they should be thrown away.Available products should be dipped for 30 minutes to 1 hour in freshly prepared 1\% sodium hypochlorite after which mutilation is expected until disposal of such items should take place under the policy.In no situations could heat be used to remove amalgam which would lead to mercury volatilization and discharge into the environment. Thus, high-level disinfectants (e.g., glutaraldehyde) can be handled for 30 minutes with amalgam-filled teeth.The pathological or chemical nature of laboratory liquid waste is evident. Non-infectious waste should be treated with reagents.The contaminated liquid waste should be processed and then disinfused with a chemical decontaminator.

8.0 LATEST TECHNOLOGIES FOR TREATMENT OF BIO-MEDICAL WASTE:

A group of specialists has been reconstituted with CPCB to evaluate emerging technologies for bio-medical waste management and to define acceptable requirements for those technologies. The CPCB has granted Plasma Pyrolysis conditional or provisional clearance under the BMW Regulations for new (non-notified under the BMW Rules) technologies for bio-medical waste management. Sharps Debris Encapsulation and dry heat sterilisation Chemical disinfection (Static/Mobile) and shredding[7].

a. $\quad$ Plasma Pyrolysis Technology:

For the handling and recycling of biological waste, the manufacturing technology of Plasma Pyrolysis can be introduced, where bio-medical waste may be destroyed similarly to the incineration. Bio-medical waste is treated under controlled conditions at high temperatures to produce secondary chamber gases such as methane, hydrogen, and carbon monoxide in plasma-pyrolysis.Waste is converted to tiny clinker and can be disposed of in stable deposits. The СРCB provisionally approved Plasma Pyrolysis Technology as an acceptable treatment choice for Bio-medical Waste Categories1,2,5, and 6 of the BMW regulations.

b. $\quad$ Waste Sharps Dry Heat Sterilization \& Encapsulation:

The technologies used in 'Waste Sharp Dry Heat Sterilization \& Encapsulation,' in particular, for the treatment of waste category 04 (i.e., waste sharps) listed in Schedule I of the 1998 BMW Rules, are based on 'dry heat sterilisation.' СРCB has approved this technology, as amended, under the Bio-medical Waste (Management \& Handling) Rules of 1998.This technology is used in waste sharps processing and post-treatment canister. 
c. $\quad$ Shredding cum Chemical Disinfection of Bio-medical Waste (Static/Mobile):

The shredding of biological matter, accompanied by chemical disinfection, is the main focus of this technology.CPCB offers a temporary clearance for the evaluation/effectiveness of the technology for the treatment on a test basis of bio-medical waste.This non-burn technology is used to remove and sterilize bio-medical waste, which is not recognized for disposal along with the urban solid waste.The 'Plasma Pyrolysis Technology' has been given conditional approval by СРCB as an alternative method for handling bio-medical waste in categories 1, 2, 5 \& 6.

\subsection{FUTURE TRENDS/DISCUSSION FOR BMWM (BIOMEDICAL WASTE MANAGEMENT)}

As the use of healthcare products has increased, PPE (Personal Protection Equipment) Kits and other health care products should be prevented by storing these with a certain symbol in doubled line sealed bags as a result of a significant increase in hazardous and infectious waste.Incineration in areas where other treatment facilities are not present is the easiest way to decontaminate. Furthermore, deep infectious waste burial in a secure landfill should be carried out in certain areas in which there is a lack of in situ or decontamination facility.Unsegregated waste can be damaging to children and women as it is most vulnerable to virus exposure as it is not properly protected. Moreover, there is a high chance of pathogens like COVID-19 being transmitted longer than the exposure of workers with waste. Thus, manual sorting time is required when unselected waste reaches the dump.

Local authorities have key responsibilities to advise the public to take responsibility. This can be achieved by reducing the amount of waste produced by proper home segregation and adhering to new biomedical waste handling and management guidelines.It is also important that the Hospital waste is properly inspected. Thus, the environment cannot be damaged. Proper information and awareness campaigns to raise awareness of the challenges facing the waste management sector during the COVID-19 pandemic should be implemented. This might be done through advertising, campaigns, articles for newspapers or social media campaigns etc.

\subsection{CONCLUSION}

The current biomedical waste management situation of Delhi is examined in this report, which should be carefully considered.In the Delhi hospitals, the biomedical waste production has suddenly increased as a result of the pandemic situation in COVID-19. The situation has worsened each day as the use of biomedical waste, such as quarantine waste andisolation wards, has rapidly increased. Because of this ongoing generation of biomedical waste, local authorities are finding it very difficult to manage such waste, since it has very negative impacts on humans, air, water and soil quality.The latest treatment technologies, such as plasma pyrolysis, autoclave and the legal framework, should also be implemented and adopted to minimise waste in the health care management system. Priority should be attached to occupational health and safety for frontline workers since they are at the early risk stage. Whenever the waste is not properly handled or separated. Public awareness of health risks associated with biomedical waste should therefore be encouraged. This should include the environmentally friendly management and disposal of waste. 


\subsection{RECOMMENDATIONS}

In order to effectively manage biomedical waste management, systems have to be refurbished. National policy is a crucial component of successful and viable biomedical waste management systems with an appropriate framework, legislation, rules and regulations. One of the primary drivers, that is the separation at source of biomedical waste, involves splitting the different categories of biomedical waste and thus reduces its level of risk. Intensive training programmes, workshops, and conferences should be offered to all medical personnel involved in the processing and disposal for biomedical waste.All junior doctors must receive specialized training in the event of an urgent need. In future directions of studies, an information, education and communications (IEC) system should be established, adequate inspection and control should be carried out on biomedical waste management. The information should be displayed by signs in each hospital, giving instructions for reuse, recycling, segregation etc, to avoid risks associated with BMW (Biomedical Waste Management). Newest treatment and innovative technologies to minimise the risk associated with biomedical waste should be implemented and taken into account.

\section{REFERENCES:}

[1] Ministry of Environment, Forest and Climate Change,Government of India, "BWM Rules, 2016," Gazette of India, Extraordinary, Part II, Section 3, Sub-section (i), 2016,[Online]. Available: https://cpcb.nic.in/uploads/Projects/BioMedical-Waste/Bio-medical_Waste_Management_Rules_2016.pdf.

[2] “Central Pollution Control Board”,[Online]. Available: https://cpcb.nic.in/covid-waste-management/.

[3] "Ministry of Environment, Forest and Climate Change, Government of India. Biomedical Waste Management Rules2016. New Delhi; 2016",[Online]. Available: http://www.indiaenvironmentportal.org.in/files/file/BMW Rules, 2016.pdf.

[4] "Ministry of Environment, Forest and Climate Change, Government of India. Biomedical Waste Management (Amendment) Rules-2018. $\quad$ New Delhi; 2018",[Online]. Available: http://www.indiaenvironmentportal.org.in/files/file/Bio medical waste management (amendment)183847.pdf.

[5] "Water , sanitation , hygiene and waste management for the COVID-19 virus," World Health Organisation, 2020,[Online]. Available: https://apps.who.int/iris/bitstream/handle/10665/331499/WHO-2019-nCoV-IPC_WASH2020.2-eng.pdf?sequence $=1 \% 26$ is Allowed $=$.

[6] P. MATHUR, S. PATAN, and A. S. SHOBHAWAT, "Need of Biomedical Waste Management System in Hospitals An Emerging issue - A Review," Current World Environment, vol. 7, no. 1, pp. 117-124, 2012, doi: 10.12944/cwe.7.1.18.

[7] "ENVIS Centre on Control of Pollution Water, Air and Noise." ,[Online]. Available:http://www.cpcbenvis.nic.in/Bio_Medical_waste.html\#.

[8] A. G. Bogoro and Y. Y. Babanyara, "Evacuation of Solid Waste in Residential Areas of Bauchi," Journal of Environmental Sciences and Resource Management, vol. 3, no. December, pp. 10-29, 2011,[Online]. Available.

[9] P. Datta, G. Mohi, and J. Chander, "Biomedical waste management in India: Critical appraisal," Journal of Laboratory Physicians, vol. 10, no. 01, pp. 006-014, 2018,[Online]. Available. doi: 10.4103/jlp.jlp_89_17.

[10] A. Borthakur and P. Singh, "Microbial Biotechnology for Sustainable Electronic Waste," Researchgate.Net, no. December, 2016, [Online]. Available: https://www.researchgate.net/profile/Anwesha_Borthakur/publication/315790803_MICROBIAL_BIOTECHNOLOGY_ FOR_SUSTAINABLE_ELECTRONIC_WASTE_MANAGEMENT/links/58e5268f0f7e9b5622f5683e/MICROBIALBIOTECHNOLOGY-FOR-SUSTAINABLE-ELECTRONIC-WASTE-MANAGEMENT.pdf.

[11] E. M. Veilla and V. M. Samwel, “Assessment of sharps waste management practices in a referral hospital,” African Journal of Environmental Science and Technology, vol. 10, no. 3, pp. 86-95, Mar. 2016,,[Online]. Available. doi: 10.5897/AJEST2015.1939.

[12] A. C. Easty et al., "Safe handling of cytotoxics: Guideline recommendations," Current Oncology, vol. 22, no. 1, pp. e27-e37, 2015,[Online]. Available. doi: 10.3747/co.21.2151.

[13] S. Mouhoun-Chouaki, A. Derridj, D. Tazdaït, and R. Salah-Tazdaït, "A Study of the Impact of Municipal Solid Waste on Some Soil Physicochemical Properties: The Case of the Landfill of Ain-El-Hammam Municipality, Algeria," Applied and Environmental Soil Science, vol. 2019,[Online]. Available: 2019, doi: 10.1155/2019/3560456.

[14] H. I. Abdel-Shafy and M. S. M. Mansour, "Solid waste issue: Sources, composition, disposal, recycling, and valorization,” Egyptian Journal of Petroleum, vol. 27, no. 4, pp. 1275-1290, 2018,,[Online]. Available: doi: 
10.1016/j.ejpe.2018.07.003.

[15] P. S Harikumar and B. Mol K, “A Synoptic Study on the Preparation of a Liquid Waste Management Plan for Kerala State, India," Environment and Natural Resources Research, vol. 2, no. 2, 2012,[Online]. Available. doi: 10.5539/enrr.v2n2p74.

[16] C. H. K. Lam, A. W. M. Ip, J. P. Barford, and G. McKay, "Use of incineration MSW ash: A review,” Sustainability, vol. 2, no. 7, pp. 1943-1968, 2010,[Online]. Available. doi: 10.3390/su2071943.

[17] E. de Souza Nascimento and A. Tenuta Filho, "Chemical waste risk reduction and environmental impact generated by laboratory activities in research and teaching institutions,” Brazilian Journal of Pharmaceutical Sciences, vol. 46, no. 2, pp. 187-198, 2010, [Online]. Available: http://www.scielo.br/scielo.php?script=sci_arttext\&pid=S198482502010000200004.

[18] "Safe management of wastes from health-care activities," WHO Press: World Health Organization, Geneva;, 2014,[Online]. Available:https://www.euro.who.int/_data/assets/pdf_file/0012/268779/Safe-management-of-wastesfrom-health-care-activities-Eng.pdf.

[19] N. S. Anurag Sharma, Ravish Garg,Anuj Srivastava, "A Study about Knowledge, Attitude, Practices and Technologies of Biomedical Waste Management Techniques.," IOSR Journal of Environmental Science, Toxicology and Food Technology, vol. 9, no. 12, pp. 73-78, 2015,[Online]. Available.

[20] "Ministry of Environment, Forest and Climate Change Notification," 2019,[Online]. Available:https://cpcb.nic.in/uploads/Projects/Bio-Medical-Waste/BMW_Amended_19.02.2019.pdf.

[21] “MINISTRY OF ENVIRONMENT, FOREST AND CLIMATE CHANGE NOTIFICATION,” 2019,[Online]. Available:https://cpcb.nic.in/uploads/Projects/Bio-Medical-Waste/BMW_Amended_10.05.2019.pdf.

[22] “Guidelines for Handling, Treatment and Disposal of Waste Generated during Treatment/Diagnosis/ Quarantine of COVID-19 Patients,” 2020,[Online]. Available: https://cpcb.nic.in/uploads/Projects/Bio-Medical-Waste/BMWGUIDELINES-COVID_1.pdf.

[23] “Annual Report on Biomedical Waste Management as per Biomedical Waste Management Rules , 2016 For the year 2018,” 2019,[Online]. Available:https://cpcb.nic.in/uploads/Projects/Bio-Medical-Waste/AR_BMWM_2019.pdf.

[24] “FORTIS HEATH CARE, SHALIMAR BAGH.”,[Online]. Available: https://www.fortishealthcare.com/india/hospitalsin-delhi-ncr/fortis-hospital-shalimar-bagh/bmw.

[25] “FORTIS HEALTHCARE, VASANT KUNJ.”,[Online]. Available:https://www.fortishealthcare.com/india/hospitals-indelhi-ncr/fortis-flt-lt-rajan-dhall-hospital-vasant-kunj/bmw.

[26] “FORTIS ESCORTS, OKHLA.”,[Online]. Available: https://www.fortisescorts.in/bio-medical-waste-report.

[27] “MAX HEALTHCARE, SHALIMAR BAGH.”,[Online]. Available: https://www.maxhealthcare.in/bio-medical-report.

[28] “MAX HEALTHCARE, SAKET.”,[Online]. Available: https://www.maxhealthcare.in/bio-medical-report.

[29] “Central Pollution Control Board,” 2020,[Online]. Available: https://cpcb.nic.in/covid-waste-management/.

[30] O. A. Al Raisi, S. A. H., H. Sulaiman, F. E. Suliman, “Assessment of heavy metals in leachate of an unlined landfill in the Sultanate of Oman.,” International Journal of Environmental Science and Development, vol. 5, no. (1), pp. 60-63, 2014,[Online]. Available.

[31] E. A. Oluseyi, T., O. Adetunde, "Impact assessment of dumpsites on quality of near-by soil and underground water: A case study of an abandoned and a functional dumpsite in Lagos, Nigeria.,” International Journal of Science, Environment and Technology, vol. 3, no. (3), pp. 1004-1015, 2014,[Online]. Available.

[32] R. G. Kanmani, S., “Assessment of heavy metal contamination in soil due to leachate migration from an open dumping site.," Applied Water Science, vol. 3, no. (1), pp. 193-205, 2013,[Online]. Available.

[33] A. R. Heera, S., "Bacterial treatment and metal characterization of biomedical waste ash. Journal of Waste Management,” Journal of Waste Management., pp. 1-7, 2014,[Online]. Available.

[34] A. S. Gautam, A., G. Pathak, “Assessment of ground water quality at municipal solid waste dumping site-Sewapura, Jaipur.," Current World Environment, vol. 6, no. (2), pp. 279-282, 2006, doi: 10.12944/CWE.6.2.12,[Online]. Available.

[35] K. I. Karthikeyan, S. R. Balasubramanian, "Particulate Air Pollution from Bushfires: Human Exposure and Possible Health Effects.,” Journal of Toxicology and Environmental Health, vol. 69, no. (21), pp. 1895-908, 2006,[Online]. Available.

[36] S. K. Javied, S., M. Tufail, "Heavy metal pollution from medical waste incineration at Islamabad and Rawalpindi, Pakistan.,” Microchemical Journal, pp. 77-81, 2008,[Online]. Available.

[37] J. Z. Zhao, L., F. S. Zhang, K. Wang, "Chemical properties of heavy metals in typical hospital waste incinerator ashes in China.," Waste Management, vol. 29, no. 3, pp. 1114-1121, 2009,[Online]. Available: doi: 10.1016/j.wasman.2008.09.003.

[38] C. D. Allen, R. J., G. R. Brenniman, “Air pollution emissions from the incineration of hospital waste,” Journal of the 
Air Pollution Control Association, vol. 36, no. (7), pp. 829-831, 1986,[Online]. Available:doi: 10.1080/00022470.1986.10466122.

[39] L. Giusti, “A review of waste management practices and their impact on human health. Waste Management,” Waste Management, vol. 29, no. (8), pp. 2227-2239, 2009,[Online]. Available: doi: 10.1016/j.wasman.2009.03.028.

[40] C. B. Coutinho, M., M. Pereira, R. Rodrigues, "Impact of medical waste incineration in the atmospheric PCDD/F levels of Porto, Portugal,” Science of the Total Environment, vol. 362, no. (1-3), pp. 157-165, 2006,[Online]. Available: doi: 10.1016/j.scitotenv.2005.06.012.

[41] O. Ephraim, I. P., A. Ita, "Investigation of soils affected by burnt hospital wastes in Nigeria using PIXE.," SpringerPlus, vol. 2, no. (1), p. 208, 2013,[Online]. Available: doi: 10.1186/2193-1801-2-208.

[42] R. Sharma, M. Sharma, R. Sharma, and V. Sharma, "The impact of incinerators on human health and environment," Reviews on Environmental Health, vol. 28, no. 1, pp. 67-72, Jan. 2013,[Online]. Available: doi: 10.1515/reveh-20120035.

[43] Y. K. G. Halder, N., S. S. Peshin, R. M. Pandey, “Awareness assessment of harmful effects of mercury in a health care set-up in India: A survey-based study,” Toxicology and Industrial Health, vol. 31, no. (12), pp. 1144-1151, 2015,[Online]. Available: doi: 10.1177/0748233713488237.

[44] S. S. Subrammani, T., P. Anitha, "Health-care waste management system.," International Journal of Engineering Research and Applications, vol. 4, no. (6), pp. 255-258, 2014,[Online]. Available.

[45] O. C. Abidemi, O. O., "Environmental fate of heavy metals in soil of Ido-Osun waste dump site, Osogbo, Osun, Nigeria.,” American Journal of Environmental Protection, vol. 3, no. (1), pp. 1-4, 2015,[Online]. Available.

[46] O. A. M. Auta, T., "Heavy metal concentrations around a hospital incinerator and a municipal dumpsite in Ibadan City, South-West Nigeria.,” Journal of Applied Sciences and Environmental Management, vol. 17, no. (3), pp. 419-422, 2013,[Online]. Available.

[47] D. Y.-T. Adama, M., R. Esena, B. Fosu-Mensah, "Heavy metal contamination of soils around a hospital waste incinerator bottom ash dumps site.," Journal of Environmental and Public Health, pp. 1-6, 2016,[Online]. Available: doi: 10.1155/2016/8926453.

[48] S. H. F. Agamuthu, P., “Heavy metal pollution in landfill environment: A Malaysian case study.," 2010,[Online]. Available.

[49] A. Y. Ali, S. M., A. Pervaiz, B. Afzal, N. Hamid, “Open dumping of municipal solid waste and its hazardous impacts on soil and vegetation diversity at waste dumping sites of Islamabad city.," Journal of King Saud University-Science, vol. 26, no. (1), pp. 59-65, 2014,[Online]. Available: doi: 10.1016/j.jksus.2013.08.003.

[50] A. S. Amfo-Otu, R., S. G. Kyerewaa, E. A. Ofori, "Comparative study of heavy metals in bottom ash from incinerators and open pit from healthcare facilities in Ghana.," Octa Journal of Environmental Research, vol. 3, no. (1), pp. 50-56, 2015,[Online]. Available.

[51] I. O. A. Adegoke, J. A., T. O. Owoyokun, "Open land dumping: An analysis of heavy metals concentration of an old lead-battery dumpsite.,” Pacific Journal of Science and Technology, vol. 10, no. (2), pp. 592-595, 2009,[Online]. Available.

[52] H. D. Demie, G., "Heavy metal pollution of soil around solid waste dumping sites and its impact on adjacent community: The case of Shashemane Open Landfill, Ethiopia.,” Journal of Environment and Earth Science, vol. 5, no. (15), pp. 169-178, 2015,[Online]. Available.

[53] Z. S. Nazir, R., M. Khan, M. Masab, H. U. Rehman, N. U. Rauf, S. Shahab, "Accumulation of heavy metals (Ni, Cu, $\mathrm{Cd}, \mathrm{Cr}, \mathrm{Pb}, \mathrm{Zn}, \mathrm{Fe}$ ) in the soil, water and plants and analysis of physico-chemical parameters of soil and water collected from Tanda Dam kohat.,” Journal of Pharmaceutical Sciences and Research, vol. 7, no. (3), pp. 89-97, 2015,[Online]. Available.

[54] C. A. U. Ukpebor, E. E., "Heavy metals concentration in the subsoil of refuse dump sites in Benin City, Nigeria.," Ghana Journal of Science, pp. 9-15, 2003,[Online]. Available.

[55] "Health impacts of health-care waste,” Safe management of wastes from health-care activities, 2015,[Online]. Available: http://www.who.int/water_sanitation_health/medicalwaste/020to030.pdf.

[56] R. L. Atmar and M. K. Estes, “Gastrointestinal tract infections,” Lennette's Laboratory Diagnosis of Viral Infections, Fourth Edition,2016,[Online]. Available: https://www.uib.cat/depart/dba/microbiologia/ADSenfcomI/material_archivos/infeccion gastrointestinal.pdf.

[57] R. Miggiano, M. Rizzi, and D. M. Ferraris, "Mycobacterium tuberculosis pathogenesis, infection prevention and treatment,” Pathogens, vol. 9, no. 5, pp. 10-13, 2020,[Online]. Available. doi: 10.3390/pathogens9050385.

[58] L. G. Harris, S. J. Foster, R. G. Richards, P. Lambert, D. Stickler, and A. Eley, “An introduction to Staphylococcus aureus, and techniques for identifyingand quantifying $\mathrm{S}$. aureus adhesins in relation to adhesion to biomaterials:Review,” European Cells and Materials, vol. 4, pp. 39-60, 2002,[Online]. Available. doi: 10.22203/ecm.v004a04. 
[59] M. P. Ravenel, “Anthrax in Man and Animals,” American Journal of Public Health and the Nations Health, vol. 30, no. 3, pp. 299-300, 2008,[Online]. Available.

[60] J. J. O. Stanley M.Lemon, "Type A viral hepatitis: A summary and update on the molecular virology, epidemiology, pathogenesis and prevention,” Journal of Hepatology, vol. 68, no. 1, pp. 167-184, 2018,[Online]. Available. doi: https://doi.org/10.1016/j.jhep.2017.08.034.

[61] X. F. Y. Justin D. Radolf, Ranjit K. Deka, Arvind Anand, David Šmajs ,Michael V. Norgard, “Treponema pallidum, the syphilis spirochete: making a living as a stealth pathogen,” Nature Reviews Microbiology, vol. 14, no. (12), 2016,[Online]. Available. doi: https://dx.doi.org/10.1038\%2Fnrmicro.2016.141.

[62] “Herpesviridae (Herpes),” 2014,[Online]. Available: https://www.lsbio.com/research-areas/infectiousdisease/herpesviridae.

[63] “Meningitis,” 2020,[Online]. Available: https://www.mayoclinic.org/diseases-conditions/meningitis/symptomscauses/syc-20350508.

[64] T. Arias-Colmenero, M. Á. Pérez-Morente, A. J. Ramos-Morcillo, C. Capilla-Díaz, M. Ruzafa-Martínez, and C. HuesoMontoro, "Experiences and attitudes of people with HIV/AIDS: A systematic review of qualitative studies," International Journal of Environmental Research and Public Health, vol. 17, no. 2, 2020,[Online]. Available. doi: 10.3390/ijerph17020639.

[65] "Haemorrhagic fevers.”,[Online]. Available: https://www.who.int/ith/diseases/haemorrhagicfevers/en/\#: :text=Cause,belong to the Flaviviridae family.

[66] “Sepsis,” 2021,[Online]. Available: https://www.mayoclinic.org/diseases-conditions/sepsis/symptoms-causes/syc20351214.

[67] “Candida Fungus Skin Infection,” 2020,[Online]. Available: https://www.healthline.com/health/skin/candida-fungus.

[68] D. Shrestha, S. B. Gokhe, A. Dhoundiyal, and P. Bothe, “A case study to review compliance to biomedical waste management rules in a tertiary care hospital," International Journal Of Community Medicine And Public Health, vol. 4, no. 2, p. 511, Jan. 2017,[Online]. Available. doi: 10.18203/2394-6040.ijcmph20170282.

[69] K. T. B. Malini R Capoor, "Current perspectives on biomedical waste management: Rules, conventions and treatment technologies,” Indian Journal of Medical Microbiology, vol. 35, no. (2), pp. 157-164, 2017,[Online]. Available: doi: 10.4103/ijmm.IJMM_17_138.

[70] J. C. Datta, Priya Gursimran Kaur Mohi, “Biomedical waste management in India: Critical appraisal,” journal of laboratory physicians, vol. 10, no. (1), pp. 6-14, 2018,[Online]. Available: doi: 10.4103/JLP.JLP_89_17.

[71] P. P. R. Sunil Kumar VC, Manjunatha. M, Badami Vijetha, “Biomedical Waste Management: a review.,” J Oral Health Comm Dent, vol. 6, no. (3), pp. 141-144, 2012,[Online]. Available.

[72] "BIO-MEDICAL WASTE MANAGEMENT-SELF LEARNING DOCUMENT FORDOCTORS, SUPERINTENDENTS AND ADMINISTRATORS,” 2011,[Online]. Available:https://www.scribd.com/document/55262437/Chemical-Safety-Bio-Medical-Waste-Management-SelfLearning-Document-for-Doctors-Superintendents-and-Administrators.

[73] K Park, Park's textbook of preventive and social medicine, Twenty-Thi. Jabalpur, India: M/s Banarsi Das Bhanot Publishers, 2015,[Online]. Available. 